\title{
SULTAN ADAM LAW IN THE PROGRESSIVE LAW PERSPECTIVE IN BANJAR COMMUNITIES IN THE 18TH CENTURY AD
}

\author{
Muhammad Fahmi Al Amruzi ${ }^{1}$, Masyitah Umar ${ }^{2}$, Anwar Hafidzi ${ }^{3}$ \\ Sharia Faculty Antasari State Islamic University \\ J. Ahmad Yani Km. 4.5 Banjarmasin, Kalimantan Selatan \\ Email: ${ }^{1}$ fahmialamruzi61@gmail.com; ${ }^{2}$ masyithah.umar55@gmail.com; ${ }^{3}$ anwar.hafidzi@gmail.com
}

\begin{abstract}
The Sultan Adam Law provides an important and interesting role in the development of the history of law in the Banjar land. This happened during the reign of Sultan Adam Al-Watsiq Billah from 1825 to 1857 AD. This Law contains matters of religion and worship, issues of Governance Law, Marriage Law, Judicial Procedures, Land Law, and Transitional Regulations. This article discusses the role of the Sultan Adam Law in the resolution of religious problems in the Banjar community in South Kalimantan and in Progressive law. The findings of this study are that the Law of Sultan Adam became the guide of the judges in deciding cases, becoming a unifying instrument of the kingdom, and an antidote to deviant sect that developed in the 18th century AD The Sultan Adam Law also exists as a progressive law, because as a a legal instrument, this law can come out of existing traditions and be able to respond to problems that occur in society at that time, and always try to constantly find new meanings and not be bound by absolute meanings. This Law is also able to act as a law that lives in the midst of society and is able to meet their needs.
\end{abstract}

Keywords: Sultan Adam's Law, Progressive Law, Banjar

Abstrak: Undang-Undang Sultan Adam memberikan peran penting dan menarik dalam perkembangan sejarah hukum di tanah Banjar. Ini terjadi pada masa pemerintahan Sultan Adam Al-Watsiq Billah dari tahun 1825 hingga 1857 M. Undang-undang ini memuat masalah-masalah agama dan peribadatan, masalah Hukum Tata Pemerintahan, Hukum Perkawinan, Hukum Acara Peradilan, Hukum Tanah, dan Peraturan Peralihan. Artikel ini membahas peran UndangUndang Sultan Adam dalam terhadap penyelesaian masalah keagamaan di masyarakat Banjar Kalimantan Selatan dan dalam hukum Progresif. Temuan penelitian ini adalah bahwa Undang-Undang Sultan Adam menjadi pegangan para hakim dalam memutuskan perkara, menjadi alat pemersatu kerajaan, dan penangkal aliran sesat yang berkembang pada abad ke-18 M. Undang-Undang Sultan Adam juga hadir sebagai hukum yang progresif, karena sebagai sebuah perangkat hukum, undang-undang ini dapat keluar dari tradisi-tradisi yang ada dan mampu memberikan respon terhadap masalah yang terjadi dalam masyarakat saat itu, serta selalu berupaya untuk terus-menerus menemukan makna-makna baru dan tidak terbelenggu pada makna absolut. Undang-undang ini juga mampu berperan sebagai hukum yang hidup di tengahtengah masyarakat dan mampu memenuhi kebutuhan mereka.

Kata kunci: Undang-Undang Sultan Adam, Hukum Progresif, Banjar

\section{Introduction}

The oldest kingdom that ever existed in South Kalimantan was the kingdom of Tanjungpura or Tanjungpuri, a kingdom of migration of Malays carrying elements of Malay culture by using Malay as the language of communication. The last kingdom was the Banjar Kingdom ${ }^{1}$.

${ }^{1}$ J.J. Ras, Hikayat Banjar a Study in Malay Historiography, (Martinus Nijhoff, The Hague, 1968), h. 191.
There are several opinions about the place where the location and position of the Tanjungpura kingdom is. One opinion is that Tanjungpura is the present city of Tanjung, whose capital is Tabalong. Furthermore according to J.J. Ras that Tanjung is an area which is the first place of Malay immigration to Kalimantan. ${ }^{2} \mathrm{Mpu}$ Prapanca mentions in Negarakartagama (1365)

\footnotetext{
2 J.J. Ras, Hikayat Banjar..., h. 191.
} 
under the name Nusa Tanjung Negara and this is identical to Tanah Hujung Island with this most important city is Tanjungpuri. In another part, MPU Prapanca mentions that Bakulapura is another name for Sanskrit to mention the name Tanjungpura. If the Tanjungpura kingdom is a migration of the Srivijaya Malays, this also means that this area has been entered the cultural elements of Buddhism as the religion of the Srivijaya kingdom. Malay migration to Kalimantan is estimated between the 12-13th century AD. ${ }^{3}$

According to A. Gazali Usman, in the 13th century, the kingdom of the Dipa State appeared which was replaced later by the Daha State. Dipa State is located around Amuntai while Daha State is located around the current State. Both kingdoms are Hindu in style with the relics of the Agung Temple and the Laras Temple. Dipa State is the kingdom of migration from East Java as a result of the war between Ken Arok and the king Kertajaya, known as the Ganter War. ${ }^{4}$

In a further development, in South Kalimantan around the 16th century was born the kingdom of Banjar which had the character of Islam and Sultan Suriansyah was the first king 5 who before embracing Islam named Prince.

The prince Samudra himself was the grandson of King Sukarama, the king of the Kingdom of Daha who gave him a will to replace him after his death, even though King Sukarama himself still had four sons and of course his four sons disagreed with the will, one of his sons was Prince Tumenggung who was very ambitious towards power of the Daha Kingdom.

When Prince Sukarama died, the office of king was held by his eldest son, Prince Mangkubumi. Prince Samudera at that time was only 7 years old. Prince Mangkubumi was not long in power. He was killed by a palace

\footnotetext{
${ }^{3}$ J.J. Ras, Hikayat Banjar..., h. 192.

${ }^{4}$ A. Gazali Usman, Urang Banjar Dalam Sejarah, (Banjarmasin: Lambung Mangkurat University Press, 1989). h. 35.

${ }^{5}$ Badri Yatim, Sejarah Peradaban Islam, (Jakarta: Rajawali Press, 1997), h. 220.
}

official at the instigation of Prince Tumenggung. After the death of Prince Mangkubumi, Prince Tumenggung replaced him as the king of the Kingdom of Daha. ${ }^{6}$

Since that, Prince Samudera became the great enemy of Prince Tumenggung. Therefore Prince Samudera chose to leave the palace and disguised himself as a fisherman in the Banjar Port, but his presence was known by Patih Masih, who controlled the Bandar. He did not want to take his region's tribute to Daha, to the Prince Tumenggung, then the Patih Still appoints Prince Samudera as King. ${ }^{7}$

Enmity between Prince Tumenggung and Prince Samudera finally gave birth to a prolonged palace conflict where Prince Samudera was the rightful heir of the Daha Kingdom ${ }^{8}$ on the basis of the will of his grandfather Prince Sukarama, the king of the Daha kingdom.

Starting from here the forerunner to the birth of the Kingdom of Banjar which originated from conflict and opposition in the royal family to a prolonged civil war. the minister Still suggested to Prince Samudera to ask for help from the Demak Kingdom when it was led by Sultan Trenggono and finally he was willing to help with the requirements for Prince Samudera to convert to Islam. Sultan Demak then sent aid in the form of a thousand soldiers along with a ruler named Khatib Dayan to convert Prince Samudera ${ }^{9}$. In the war against Prince Tumenggung with the help of the Sultan of Demak's work, Prince Samudera won a victory and in accordance with his promise, he and all relatives of the palace and the people of Banjar declared themselves converted to Islam. ${ }^{10}$ After converting to Islam in $1526 \mathrm{AD}$, the Daha Kingdom immediately changed to the Banjar

\footnotetext{
${ }^{6}$ Badri Yatim, Sejarah Peradaban Islam..., h. 121.

${ }^{7}$ Harun Yahya, Kerajaan Islam Nusantara: Abad XVI Dan XVII, (Yogyakarta: Kurnia Kalam Sejahtera, 1995), h. 72

8 Saifuddin Zuhri, Sejarah Kebangkitan Islam dan Perkembangannya di Indonesia, (Bandung: Al-Ma'arif, 1979), h. 386.

${ }^{9}$ Saifuddin Zuhri, Sejarah Kebangkitan..., h. 220

${ }^{10}$ J.J Ras, Hikayat Banjar..., h. 426.
} 
Islamic Kingdom and Prince Samudera was given the title Sultan Suryanullah or Sultan Suriansyah and was named the first king in the Banjar Islamic Kingdom. ${ }^{11}$

The city of Banjarmasin was made the capital of the Banjar Kingdom and since then the city of Banjarmasin began to develop into a large trading port. Traders from various tribes came to Banjarmasin to look for various merchandise such as black pepper, rattan, dammar, gold, diamonds, honey, and animal skins. ${ }^{12}$

The Banjar Kingdom was Islamic in style and made Islam the State religion and placed the ulemas in a respected place within the State. The Banjar kingdom developed rapidly until the 19th century and was an independent Islamic kingdom with the Banjar nation as citizens of a kingdom. ${ }^{13}$

The position of Islam as the State religion is clearly seen during the reign of Sultan Adam (1825-1857 AD), he obtained the title of Sultan Muda since 1782. He issued the State Law in 1835 which came to be known as the Law of Sultan Adam, in The law is clear that the source of law used is Islamic law. ${ }^{14}$

\section{Get to Know the Banjar King "Sultan Adam"}

Sultan Adam bin Sultan Sulaiman Rahmatullah bin Sultan Tahmidillah II, born in 1876 AD on Karang Anyar earth (Karang Intan), Banjar Regency, South Kalimantan. ${ }^{15}$ Sultan Adam is the eldest son of Sultan Sulaiman Rahmatullah, and has as many as 5 relatives and 17 relatives, so there are 22 siblings; thus the son of Sultan Sulaiman Rahmatullah numbered 23 people. $^{16}$

\footnotetext{
${ }^{11}$ Badri Yatim, Sejarah Peradaban Islam..., h. 121.

12 Suriansyah Idham, Urang Banjar dan Kebudayaannya, (Banjarmasin: Badan Penelitian dan Pengembangan Daerah Provinsi Kalimantan Selatan dan Putaka Benua, 2007), h. 20.

${ }^{13}$ A. Gazali Usman, Urang Banjar Dalam Sejarah, Lambung Mangkurat University Press, Banjarmasin, 1989, h. 3.

${ }^{14}$ Undang-Undang Negara, Undang-Undang Sultan Adam, h. 1835 .

${ }^{15}$ Gusti Khairul Saleh, Manaqib Sultan Adam Al-Watsiq Billah Martapura Kalimantan Selatan, (Kalimantan Selatan: Yayasan Sultan Adam Al-Watsiq Billah, 2001), h. 6.

${ }^{16}$ Gusti Khairul Saleh, Manaqib Sultan Adam..., h. 6.
}

Sultan Adam was a fair and wise person, so he was able to unite his wives as many as four people in one house, when one of his wives died, he remarried so that his wife still numbered four people until the end of his life. And his wife totaling five people and had as many as 11 people. ${ }^{17}$

According to Syamsir Seman, Sultan Adam was a wise sultan because he always tried to advance the welfare of the people. Then as a Sultan who can be called santri because he showed concern for the advancement of the welfare of the Islamic Religion. ${ }^{18}$

In the lineage of Sultan Adam's descendants including the 18th king ruled in the Banjar Kingdom, this is based on the ranji or genealogy followed by his descendants better known as the version of the unity ${ }^{19}$, as well as those contained in Manaqib Sultan Adam Al-Watsiq Billah which is read on 148th Haul (4 June 2001). ${ }^{20}$

When viewed from the time the Banjar kingdom was held by Pangeran Samudera (the first king who embraced Islam, with the title Sultan Suriansyah), then Sultan Adam was the 12th king of the Banjar Sultanate lineage.$^{21}$

There is a difference of opinion regarding the position of Sultan Adam as the king who governs in the kingdom of Banjar. According to H. Gusti Shuria Roem; one of the members of the drafting team of History of Sultan Adam and similar to that put forward by a prominent scholar Sheikh Abdurrahman Shidiq Al-Banjari or better known as Sheikh Abdurrahman Shidiq Sapat (1857-1939) in his famous "Risalah Sejaratul Arsyadiyah" which states that Sultan Adam is the 18th Sultan. ${ }^{22}$

\footnotetext{
${ }^{17}$ Gusti Khairul Saleh, Manaqib Sultan Adam..., h. 6.

${ }^{18}$ Samsiar Seman, "Meninjau Naskah Lama Undang-undang Sulthan Adam", Majalah Orientasi, No. 2 Tahun. II, 1977, h. 3.

19 H. Gusti Shuria Rum, "Ranji/Silsilah Raja/Sultan Kerajaan Banjar Versi Pedatuan", Makalah pada Acara Sarasehan Sejarah Kerajaan Banjarmasin, Banjarmasin, 2003, h. 6

${ }^{20}$ Gusti Khairul Saleh, Manaqib Sultan Adam..., h. 6

${ }^{21}$ Syeik Abdurrahman Shiddiq, Risalah Sejaratul Arsyadiyah, (Singapura, Jakarta: Maktabaah Ahmadiyah, 1937), h. 100. h. 100 .
} 
While in another version mentions that Sultan Adam is the 20th sultan in the order of the Banjar kings starting from Soeria Anata as J. Eisenberger placed Sultan Adam as the 20th Sultan in the order of Banjar kings starting from Soeria Anata. ${ }^{23}$ This opinion was followed by Amir Hasan Bondan ${ }^{24}$, Yusuf Halidi ${ }^{25}$ and Noorlander. ${ }^{26}$ This opinion was also followed by M. Idwar Saleh. ${ }^{27}$ Then another opinion states that Sultan Adam is the 11th Sultan in the order of the Banjar kings, as quoted from Kyai Haji Januri bin Haji Roys. ${ }^{28}$

In the book History of Banjar published by the Provincial Government of South Kalimantan, it is stated that Sultan Adam ranks 16th in the lineage of the king of the Banjar kings, ${ }^{29}$ as well as Gazali Usman in his book The Kingdom of Banjar History Development of Political Economy, Trade and Religion of Islam places Sultan Adam in the first place 16 in the lineage of the Banjar kings. ${ }^{30}$

\section{Progressive Law}

Understanding Progressive literally is favoring new, modern ideas, happening or developing steadily $^{31}$ (welcoming new directions, modern

${ }^{23}$ J. Eisenberger, Nota Betreffende Godsdienstige Rechtspraak en de Posietie der Godsdienstige Functionarissen in The Afdeeling Banjarmasin en Hoeloe Soengai der Residentis en Oosterafdeeling Banjarmasin en Hoeloe Soengai der Residentie Zuider en Oosterafdeeling Borneo, (Kern Colectie, 1936), h. 113

${ }^{24}$ Amir Hasan Kiai Bondan, Suluh Sejarah Kalimantan, (Banjarmasin: Fajar, 1953), h. 68

${ }^{25}$ Yusuf Halidi, Ulama Besar Kalimantan Selatan Syekh Muhammad Arsyad Al Banjari, (Surabaya: Al Ihsan, 1984), h. 10.

${ }^{26}$ Johanes Cornelis Noorlander, Banjarmasin en de Compagnie in de tweede helf der 18de Eeuw, (Leiden: M. Dubbeldeman, 1935), h. 90.

${ }^{27}$ M. Idwar Saleh, Banjarmasin, Selayang Pandang Mengenai Bangkitnya Kerajaan Banjarmasin, Posisi, Fungsi, dan Artinya dalam Sejarah Indonesia dalam Abad ke 17, (Bandung: Balai Pendidikan Guru, 1957), h. 102

${ }^{28}$ Kyai Haji Januri bin Haji Roys, Sejarah Kerajaan Banjar, (Singapura: Al Ahmadiyah, 1975), h. 19.

${ }_{29}$ Pemerintah Propinsi Kalimantan Selatan, Sejarah Banjar, (Banjarmasin: Pemerintah Propinsi Kalimantan Selatan, 2003), h. 290.

${ }^{30}$ A. Ghazali Usman, Kerajaan Banjar Sejarah Perkembangan Politik Ekonomi Perdagangan dan Agama Islam, (Banjarmasin: Lambung Mangkurat University Press, 1994), h. 298.

${ }^{31}$ Oxford Learner's Pocket Dictionary (New Edition), Oxford: Oxford University Press), Edisi ketiga, h. 342. ideas, steady events or developments), or eager to move forward, always (more) advance, increase. ${ }^{32}$ Progressive is derived from the word progress which means progress, desire and always progressing. ${ }^{33}$

Simply put, Satjipto Rahadjo explained that progressive law is a law that liberates both ways of thinking and acting in law, so that it is able to let the law flow only to complete its task of serving human and humanity. So there is no engineering or partiality in upholding the law, because according to him the law aims to create justice and prosperity for all people. ${ }^{34}$

The concept of progressive law that was born and developed cannot be separated from the dissatisfaction of the community from the legal community against the theory and practice of traditional law that criticizes the existence of a gap between the law in theory (law in books) with the law in reality (law in action) as well as the existence of legal failure in provide responses to problems that occur in society. ${ }^{35}$

Progressive law means law that cares for humanity so that it is not merely dogmatic. Progressive law is specifically referred to as "propeople law" and "pro-justice" (substantial). ${ }^{36}$ The concept of progressive law is that law does not exist for its own sake, but for a purpose that is outside of itself. Therefore progressive law leaves the analytical jurisprudence or rechtsdogmatiek tradition. ${ }^{37}$

According to Satjipto Rahardjo "Law is an institution that continuously builds and changes

\footnotetext{
32 Pius A Partanto dan M. Dahlan Al Barry, Kamus Ilmiah Populer, (Surabaya: Arkola, 2001), h. 628.

${ }^{33}$ Sulchan Yasyin, Kamus Intar Bahasa Indonesia, (Surabaya: Penerbit Amanah, 1995), h. 83

${ }^{34}$ Satjipto Rahardjo, Ilmu Hukum; Pencarian, Pembebasan dan Pencerahan, (Surakarta: Muhammadiyah Press University, 2004), h. 17

${ }^{35}$ Satjipto Rahardjo, Membedah Hukum Progresif, (Jakarta: Penerbit Kompas, 2007), h. 228

${ }^{36}$ Satjipto Rahardjo, Hukum Progresif Sebuah Sintesa Hukum Indonesia, (Yogyakarta: Genta Publishing, 2009) h. 2.

${ }^{37}$ Reza Rahmat Yamani, "Pemikiran Prof Satjipto Rahardjo Tentang Hukum Hukum Progresif dan Relevansinya Dengan Hukum Islam di Indonesia”, Tesis Fakultas Syariah dan Hukum UIN Alauddin Makasar, 2016 h. 19.
} 
itself towards a better level of perfection. The quality of its perfection can be verified into factors of justice, welfare, care for the people and others " 38

Progressive law is in line with legal realism, according to this school the source of law is not the sole authority of the state, but law enforcers, especially judges, the form of law is no longer a law but a judge's decision and actions decided by law enforcers. The aim of legal realism, according to Olever Wener Hiolmes, is to make law listen more to social needs. ${ }^{39}$

Legal progressism teaches that law is not a king, but a tool to describe the basis of humanity which functions to give grace to the world and humans. According to Satjipto Rahardjo: Law is for humans and not vice versa. The law is not for himself but for something broad, namely for human dignity, happiness, welfare and human glory. Law is not an absolute final institution because law is always in the process of continuing to be a law (law as a procces, law in making) ${ }^{40}$

\section{The Law of Sultan Adam (UUSA)}

In a legal study, an interesting thing in the history of the Banjar Sultanate occurred during the Banjar Sultanate which was led by Sultan Adam Al-Watsiq Billah (in power 1825-1857 AD). During his reign, the sultan had succeeded in implementing an Islamic law in the land of Banjar, which he embodied in a law known as the "Law of Sultan Adam (1835 AD)". ${ }^{41}$ This law was born and established by Sultan Adam 10 the year after he was crowned king of the banjar. $^{42}$

\footnotetext{
${ }^{38}$ Satjipto Rahardjo, Hukum Progresif..., h. 6.

${ }^{39}$ Philipe Nonet dan Philipe Selznick, Law in Society in Transition Toward Responsive Law, diterjemahkan oleh Refael Edy Basco Hukum Responsif Pilihan di Masa Transisi, (Jakarta: HUMA, 2003), h. 59-60.

${ }^{40}$ Satjipto Rahardjo, Membedah Hukum Progresif, h. 154.

${ }^{41}$ Gusti Khairul Saleh, Manaqib Sultan Adam Al-Watsiq Billah, http://kesultananbanjar.com/id/manaqib-sultan-adamal-watsiq-billah/ (28 Maret 2017).

${ }^{42}$ Sjarifuddin, et al., eds., Sejarah Banjar, ed. M. Suriansyah Ideham, et al., eds. (Banjarmasin: Badan Penelitian dan Pengembangan Daerah, 2007), h. 17.
}

In general, the 18 th century in the archipelago was a time when Dutch colonialism began to become inflamed. The political turmoil of colonialism had a great influence even though it was initially only for economic matters. All the kingdoms in the archipelago at that time had the same economic opponents as well as political opponents, which in the end these regions fell into the grip of the Western invaders. ${ }^{43}$

Likewise what happened in the Banjar Kingdom, Sultan Adam, known as a ruler who worked hard to maintain the integrity of the Kingdom, is interesting from the time of Sultan Adam is survival that is not politically based but through law. From this, it is possible that the existence of a legal institution is a manifestation of the bargaining of interests between the ruling elite and the community elite. That is, legal institutions are not purely within the normative space but also social sub-strata. ${ }^{44}$

In the early days of his reign the conditions were very controlled, safe and peaceful. But after about ten years of rule, political life, state and society and religion began to flare up, because the Dutch invaders began to openly want to control the Banjar Kingdom, coupled with the arrival of Christian missionaries led by Reverend Barntein. Gradually the territory of the Banjar Kingdom began to narrow. Beginning in 1787 , which was lost by the Dutch, continued to diminish in 1826, until it became very narrow which only covered areas inhabited by ethnic Banjar tribes under the rule of Sultan Adam alWasik Billah. ${ }^{45}$

The Banjar Kingdom at the time of Sultan Adam was already under Dutch rule and was only a vassal state even though it was still recognized as a Kingdom. Dutch policies were difficult for Sultan Adam to heed. Because, political power is very weak. Nevertheless, the Netherlands still

43 W. F. Wertheim, Masyarakat Indonesia dalam Transisi, alih bahasa Zulfa Elizabet, (Yogyakarta, Tiara Wacana, 1999), h. 42-48.

${ }_{44}$ M. Faqih de Ridha, "Potret Lain Perjalanan Hukum di Kerajaan Banjar”, Al-Banjari, Vol. 12, No.1, Januari 2013, h. 15.

45 Sjarifuddin, et al., eds., Sejarah Banjar, h. 17. 
gave Sultan Adam space to lead the community. ${ }^{46}$

Seeing such a situation, the wise Adam with his love for Islam, tried to fend off and ward off foreign cultures and situations that threatened the unity and integrity of the kingdom, Sultan Adam felt the need to make laws with the intention of maintaining and strengthening the people's trust in Muslim.

In realizing his intention, Sultan Adam formed a team led directly by Sultan Adam and assisted his son-in-law Prince Syarif Hussien, and Mufti Haji Jamaluddin bin Shaykh Muhammad Arsyad and others. ${ }^{47}$

In the preparation of UUSA, many major ulemas involved, even in Article 31 it was mentioned that the role of ulema Mufti Haji Jamaluddin as a "resource" for the preparation of UUSA. Mufti Haji Jamaluddin himself was the son of Sheikh Muhammad Arsyad Al Banjari and was a Banjar cleric at the time of Sultan Adam. ${ }^{48}$

As the son of Sheikh Muhammad Arsyad Al Banjari, of course his ideas and knowledge were inherited from his parents as well as Sultan Adam as the team leader who admired Sheikh Muhammad Arsyad Al Banjary's character, especially during his youth, Sultan Adam, son of Sultan Sulaiman, was a student of Shaykh Muhammad Arsyad Al-Banjary which is certainly not excessive when the birth of UUSA was also inspired by several breakthroughs made by Sheikh Muhammad Arsyad Al-Banjary in the era of Sultan Tahmidillah II (1561-1801). At that time Islamic law began to institutionalize in the Banjar Kingdom accompanied by Sheikh Muhammad Arsyad Al-Banjari, a great scholar who had succeeded in fostering the Banjar people to practice Islamic teachings. The idea of Sheikh Muhammad Arsyad Al-Banjary formed the Mufti and Qadhi institutions, which implemented Islamic Sharia. ${ }^{49}$

${ }^{46}$ M. Faqih de Ridha, “Potret Lain Perjalanan..., h. 15.

${ }^{47}$ Sjarifuddin, et al., eds., Sejarah Banjar, h. 221.

${ }^{48}$ Abdu r rahman, "Undang-Undang Sultan Adam 1835 Dalam Perspektif Sejarah Hukum”, Al Banjari, Vol. 10, No. 2, Juli 2011, h. 190.

${ }^{49}$ Yusuf Halidi, Syek h Muhammad Al-Banjari Ulama Besar
Shaykh Arsyad Al-Banjary in his daily life besides teaching at Islamic boarding schools in the Martapura fence to educate the preachers, he also a uthored various books as a guide for Muslims, among the books he wrote were:

1. Kitab Faraidh, related to inheritance issues and how they are distributed.

2. Kitabunnikah, contains an understanding of the guardian and how to contract marriage

3. Kitab Tuhfaturraghibien, contains an explanation according to the Ahlussunahwal Jamaat to remove the habit that causes people to slip towards syirik and murtad.

4. Kitab Kanzu Ma'rifah, the book that discusses the problem of Sufism.

5. Sabilu Mubtadin Lit-Tafaqquh Fi Amriedien, The Book of Fiqh in Malay, very deep Arabic letters accompanied by various difficult problems.

The Book of Sabilul Muhtadin Lit-Tafaqquh Fi Amri edien is very well known throughout Southeast Asia such as the Philippines, Malaysia, Singap o re, Thailand, Indonesia, Brunei Daruss a lam, Cambodia, Vietnam, and Laos, because the Muslims in these areas still use Malay ${ }^{50}$

Shaykh Arsyad Al Banjary is highly respected by the Sultan because of the depth of his knowledge and his book Sabilul Muhtadin for a king who has a great influence and gives understanding and ingenuity in improving all the work of religion and the work of the world "Sultan Tahmidillah himself when he was about to die testified to his descendants that: "Shaykh Muhammad Arsyad is a friend of mine and he is also a teacher of mine, then I will testify to my grandchildren for generations do not be disobedient to him and his childre n and grandchildren and zuriat, if he is not safe he is safe". The sultan's relationship was further strengthened by marriage ties, when the Sultan married Sheikh Muhammad Arsyad with

Kalimantan Selatan Silsilah Raja-raja yang Berkuasa Pada Masa al-Banjari dari Lahir Hingga Wafat (Surabaya: Al-Ihsan, 1968), h. 25 .

${ }^{50}$ M. A rsyad al-Banjari, Kitab Sabilal Mubtadin, terj. M Asywadie Syukur (Surabaya: PT Bina Ilmu, 1985), h. 2. 
his granddaughter Ratu Aminah, the daughter of Prince Thoha bin Sultan Tahmidillah. ${ }^{51}$ That is why the thought of Shaykh Arsyad Al Banjary greatly inspired his descendants, including Sultan Adam.

The purpose and purpose of Sultan Adam issuing this law is illustrated in his consideration which states that this law was made for all his people with the intention:

1. To perfect the religion and beliefs of its people.

2. To prevent it, there should not be many conflicts between the people.

3. To make it easier for judges to determine the law.

4. And as the final goal of the enactment of the law is that the people can be good. ${ }^{52}$

UUSA includes religious and worship issues, Governance Law Issues, Marriage Law, Judicial Procedures, Land Law, and Transitional Regulations $^{53}$

The manuscript of the Sultan Adam Act as contained in Joekes' writing in 1881 which was later republished in the 1917 Adatrechts Bundle is only one of several versions of the Sultan Adam Law. Similar texts have also been published by Banjar historian Amir Hasan Bondan (18821967) in his book Suluh Kalimantan History (1953) which was later published in the Orientation Magazine of the Faculty of Law at the University of Lambung Mangkurat (1977) and the Sultan Adam Law Academy during a discussion on the date October 22, $1986 .{ }^{54}$

In the book "History of the Banjar" the UUSA manuscript is presented in full according to the Martapura version of Article 1 to Article 31 while according to the Amuntai version up to Article $38 . .^{55}$ UUSA has its own systematics

\footnotetext{
51 Abu Daudi, Maulana Syeikh Muhammad Arsyad alBanjari, (Kalimantan Selatan: Sekretariat Madrasah Sullamul Ulum, 1980), h. 45.

52 Abdurrahman, Undang-undang Sultan Adam..., h. 12.

${ }^{53}$ Amir Hasan Kiai Bondan, Sulub Sejarah Kalimantan, h. 33.

${ }^{54}$ Abdurrahman, "Undang-Undang Sultan Adam 1835...", h. 182.

${ }_{55}$ Pemerintah Provinsi Kalimantan Selatan, Sejarah Banjar,
}

in accordance with the mindset at the time, as a case to mention the meaning of the article for example. The material of this law can be classified as follows.:

1. Religious issues at worship, including:

Article 1: Issues of trust.

Article 2: Establish a place of worship and worship in congregation.

Article 20: Obligation to see the beginning of Ramadhan fasting month.

2. Governance Law Issues, including:

Article 3: Obligations of the village.

Article 21: Obligations to protect the village.

Article 31: Obligations of Lurah and Mantri.

3. Marriage Law, includes:

Article 4: Conditions of marriage.

Article 5: Conditions of marriage.

Article 6: Divorce.

Article 18: Mining

Article 25: Accuse wife of adultery.

Article 30: Adultery.

4. Judicial Procedures, including:

Article 7: Duties of the Mufti.

Article 8: Duties of the Mufti.

Article 9: Prohibition of litigants comes to officials

Article 10: Judges' duties.

Article 11: Implementation of the decision.

Article 12: Confirmation of decision.

Article 13: Bilal and folk obligations.

Article 14: Indictment.

Article 15: The period of time for a lawsuit to sue.

Article 19: Prohibition of kings or paramedics interfering in civil matters unless there is a letter from the Judge.

Article 24: The judge's obligation to examine the case.

(Banjarmasin: Pemerintah Provinsi Kalimantan Selatan, 2003), h. $154-163$. 
5. Land Laws, including:

Article 17: Land Pawn.

Article 23: Issue of expiration.

Article 26: Land lease.

Article 23: Land management.

Article 29: Discharge of land.

6. Transitional Rules, including: Article $16 .{ }^{56}$

Judging from the systematic UUSA this is not a good law according to the size of today's regulations. UUSA consists of 31 articles (called cases, but in Dutch translated with articles meaning articles). The order of the articles is not arranged in groups according to the problems they regulate, but sometimes it jumps and is interspersed by articles that have no connection with the previous provisions. Likewise, the transitional rule does not appear at the end of the rule, but it does exist at the middle. ${ }^{57}$

However, this UUSA is considered a law that can improve the religious values of the community and at the same time can be used as a guide for judges in deciding cases. In addition, the Law of Sultan Adam is considered as a unifying tool of the kingdom and at the same time serves as an antidote and a supervisor of the schools that are considered heretical, because the king wants only a flow in the religious life of the community, namely the Syafi'i school of ablusunah waljamaah which based on Sunni ideals and S amaniyah ideology as the only school of thought in the Banjar kingdom, while on the other hand there is Sheikh Muhammad Nafis and or Sheikh Abdul Hamid Abulung who developed a s c hool or school called wahdatul wujud (the union of God with beings). who are considered heretics. ${ }^{58}$

This UUSA is very simple and co $\mathrm{n}$ sisting of only two parts, namely the Introduction or

${ }^{56}$ Pemerintah Provinsi Kalimantan Selatan, Sejarah Banjar, h. $151-152$.

${ }^{57}$ Abdurrahman, "Undang-Undang Sultan Adam 1835...", h. 186 .

${ }^{58}$ Rustam Effendi, "Struktur dan Makna Undang-undang Sultan Adam pada Masa Kerajaan Banjar Kalimantan Selatan”, LITERA, Jurnal Penelitian Bahasa, Sastera dan Pengajarannya, Vol. 12, No. 2, Oktober 2013, h. 260.
Preamble which only contains one pragraph, and the Body or content section containing 31 articles, and is equipped with Transitional Regulations. ${ }^{59}$

\section{Shades of Progressive Law in UUSA}

A very interesting development in the history of law in the Banjar land occurred during the reign of the 18th King of Banjar, ${ }^{60}$ namely when the Sultan Adam ruled from 1825 to 1857 AD which presented a law which became known as the Law of Sultan Adam (UUSA).

UUSA is a legal product of the past in the kingdom and the Banjar community which pretty much reveals the facts of the past both with regard to history, law, politics and religious issues that have a considerable influence on the life of today's society.

UUSA as a historical document, this law contains the living law principles of the Banjar Society maintained by the Banjar kingdom which certainly prevailed until the dissolution of the Banjar kingdom by the Dutch government in 1860. Perhaps this manuscript is one the only historical documents left from the government of the Banjar kingdom since its foundation in 1526 until the dissolution of the kingdom in $1860 .{ }^{61}$

As a historical document, from the beginning until now it contains the legal principles of life of the Banjar Society which were defended by the Banjar kingdom which certainly prevailed until the dissolution of the Banjar kingdom by the Dutch government in $1860 .^{62}$

Islamic law as a law that lives in banjar society is implemented and practiced in the life of happiness; when Islamic law is learned from religious scholars and teachers by listening and memorizing and carried out under the guidance of religious scholars and teachers; in accordance with the conditions at that time there were not many people who were literate, so the religious

\footnotetext{
${ }^{59}$ Abdurrahman, Undang-Undang Sultan Adam..., h. 123-130.

${ }^{60}$ Syekh Abdurrahman Shiddiq, Risalah Sejaratul Arsyadiyah, h. 101.

${ }^{61}$ Abdurrahman, Undang-Undang Sultan Adam..., h. 166.

${ }^{62}$ Abdurrahman, Undang-Undang Sultan Adam..., h. 166.
} 
law was transformed like customary law.

Banjar society is a society known for its Islamic (tradition) and this continues on the issue of social obedience. Society is more obedient to religious leaders than rulers. So that the legal authority exercised by the ulama contains both formal and non formal compliance. This also shows that the historical legal motion that occurs according to social travel when it is more likely to use Islamic social rules rather than general or secular rules. On the other hand, that is, within the ruler (Sultan), it does not consider a problem if the social rules of society are based on Islamic law. The first reason, the people at that time had long embraced Islam. Second, the ulama factor is a figure that can be accepted by all parties and becomes a social glue. ${ }^{63}$

Such fact is that UUSA in the perspective of legal studies is placed within the framework of Customary Law studies. An expert on customary law Van Vollenhoven (1874-1933) in his book "Het Adatrecht Van Nederlandsch Indie" (1905) explained about Vindplaatsen van het adatrecht (sources where to find customary law), one of which was "Verordeningen van vorsten en hoefden" (1905) The rules of the kings and community leaders) later called "geshreven adatrecht" or "explicit customary law", as opposed to "ongeschreven adatrecht" or "unwritten traditional law". In this regard Van Vollenhoven mentions "Vorstenedikten in dezen trant zijn nog uit tal van streken over, en comment in de tweede afdeeling bij Atjeh (sarakata's) bij zuid Borneo (Sultan Adam) bij Bolaang Mongondou enz". ${ }^{64}$

Actually the birth of UUSA shows the process of the development of Islamic law in the Banjar Kingdom, because this law is based on the principles of Islam that were thick at that time. This law was issued by Sultan Adam after 10 years he ruled from the year of his coronation, the aim was to mobilize the influence of Western

${ }^{63}$ Alfani Daud, Islam dan Masyarakat Banjar; Deskripsi dan Analisa Kebudayaan Banjar, (Jakarta: RajaGrafindo Persada, 1997), h. 57.

${ }^{64}$ Van Vollenhoven, Het Adatrecht Van Nederlandsch Indie, (t.t: t.p, 1905), h. 113. culture and strengthen the unity and unity of the kingdom and the integrity of the people of Banjar.

In implementing this legal product, Sultan Adam held changes and perfected the structure of his government. Hierarchically it starts from Mufti, Supreme Judge, Supervisor of the General Court; Qadi; Head of Islamic Legal Affairs; Penghulu, Low Judge; Lurah, directly as a Helper Lalawangan and observing the work of several people Pambakal (Kepala Kampung) assisted by Khalifah, Bilal, and Kaum; Pambakal, Kapala Kampung who controlled several village children; Mantri, Rank of honor for prominent people and meritorious, some of them have become village heads in the same area as Lalawangan; Tatulia Kampung, a prominent person in the village; and Panakawan, the person who was ordered by the king, was freed from all kinds of taxes and obligations. ${ }^{65}$

For 32 years Sultan Adam ruled in the Land of Banjar, bringing his people to prosper, upholding the teachings of ahlussunah wal jamaah, improving the economy and agriculture and spearheading teaching and learning activities in the field of religious knowledge, and defending the kingdom from attacks by the Dutch colonial invaders. ${ }^{66}$

According to Abu Daudi, Sultan Adam has succeeded in applying Islamic law in the Kingdom of Banjar and Banua Lima, which he embodied in one law so that his people actually carry out the teachings of Ahlusunnah wal Jamaah, and he included in them religious institutions in the government structure. He was very concerned about the development of religion Islam ${ }^{67}$, and he is also highly respected and respected by both his people and the Netherlands ${ }^{68}$

According to A.M. Joekes, Sultan Adam was an ordinary king and not a famous jurist but he

${ }^{65}$ Amir Hasan Kiai Bondan, Suluh Sedjarah Kalimantan, h. $149-150$.

${ }^{66}$ Gusti Hairul Saleh, Manaqib Sultan Adam..., h. 14.

${ }^{67}$ Amir Hasan Kiai Bondan, Suluh Sedjarah Kalimantan, h. 35

${ }^{68}$ Gusti Hairul Saleh, Manaqib Sultan Adam..., h. 4. 
had a very high sensitivity to the conditions of the people in his area ${ }^{69}$

The law stipulated by Sultan Adam, although it only consists of 31 articles, can describe the situation and condition of the community and its legal conditions. The substance of the Islamic nuances are influenced and inspired by the thought of Sheikh Muhammad Arsyad Al Banjari, one example is the idea of Sheikh Muhammad Arsyad Al-Banjary to establish Mufti and Qadhi institutions which implement Islamic Sharia in the era of Sultan Tahmidillah (1561-1801), and in the UUSA there is a special material that contains the Judicial Procedure Law which was later defended by the Dutch Colonial government for South Kalimantan in 1937 and even applies today under the name Qadhi Density and Large Qadhi Density in the justice system as contained in a research report conducted by Eisenberger in preparing the formation of "Kerapatan Qodi” and "Kerapatan Qodi Besar" in So u th Kalimantan as an appendix to his report entitled "Onwerp Nopens Regeling Van de Godscchenstige Rechtspraak in de Bandjereezen gebied der zuider en Ooster afdeeling van Borneo" July 26, 1936 No. 1560 / B 1-3, as subsequently determined by Stb 1937 No. 638 and No. $639 .^{70}$

Likewise with legal matters regarding marriage, which Sheikh Muhammad Arsyad Al Banjary discussed in a book entitled "Kitab al Nikah" by his own work, in this book explained the ins and outs of marriage law, and in the Law of Sultan Adam there special articles describing matters relating to marriage totaling 6 articles, namely contained in article 4 , article 5 , article 6 , article 18, article 25 and article 30 . At present the legal issues concerning marriage are contained in the law a separate law, namely Law No. 1 of 1974 concerning Marriage and continued in the form of a Compilation of Islamic Law (KHI) on the basis of its implementation through a Presidential Instruction.

${ }^{69}$ A.M. Joekes, Oendang-oendang Soelthan Adam, (Adatrehts Bundel, Dell XIII, 1917), h. 149.

${ }^{70}$ Abdurrahman, Undang-Undang Sultan Adam..., h. 184.
Likewise with other legal issues such as religion and worship, governance and land tenure laws contained in the Sultan Adam Act. These laws are laws that are close and in direct contact with people's lives and now each of these laws has its own place in legislation.

The existence of Sultan Adam's law at that time really provided answers and solutions to the legal problems faced by the community and at the same time guided and guided the community to a better life. This is what Satjipto Rahardjo said that the law is for humans, not the other way around. The law is not for himself but for something broad, namely for human dignity, happiness, welfare and human glory. Understanding the law for humans is meant by Satjipto Raharjo is a law that can deliver humans to a just, prosperous life and make people happy.

Progressive law and Islamic law have two core characteristics, namely law for humans and refuse to maintain the status quo in law, then the idea of progressive law and Islamic law is compatible. When viewed from the principles of Islamic law in general, the principles of Islamic law are in accordance with the characteristics of progressive law, namely the law for (the interests of) humans. Whereas ijtihad as a way to make Islamic law in accordance with every era is in accordance with the characteristics of refusing to maintain the status quo in law. ${ }^{71}$

UUSA is present as a progressive law, as a legal instrument, this law can come out of existing traditions and be able to respond to problems that occur in society at that time. Progressive law like this is in line with legal realism which, according to O lever Wener Hiolmes, aims to make law listen more to social needs.

Although this law is quite simple but it is considered quite perfect, because in this law it is enough to provide answers to every problem

${ }^{71}$ M. Yudi Fah i ra, dalam Dina Asterina, "Penerapan Hukum Progresif Pasal 39 Undang-Undang Nomor 1 Tahun 1974 Tentang Perselisihan Suami Isteri di Pengadilan Agama Martapura”, Tesis Pascasarjana IAIN Antasari Banjarmasi, 2014, h. 16. 
faced by society and the country at that time and even considered quite advanced because this law can provide guarantees of justice and certainty, security and peace, comfort and prosperity, this can be proven by the recognition of various groups, including by the Dutch colonial people.

The key to a progressive law is where it always seeks to continually find new meanings and not be bound by absolute meanings. Creativity to make the law the living law; the law that lives in the midst of society and continues, because the laws set forth in the form of written language must always be interpreted dynamically, because language itself basically reflects the development of society and its culture.

Satjipto Rahardjo said that law is not only the building of regulations, but also the building of ideas, culture and ideals, people often see the law only as a rule and procedure, all of which are very dependent on the textual rules in the legislation, all of which are has a "neutral" connotation. ${ }^{72}$

Such conditions made the Sultan Adam and the Law he issued get a response from the Dutch colonial government. Dutch admiration for the Act of Sultan Adam made the Governor of Borneo (1891-1894), AM Joekes, publish it in the Indische Gids Magazine in 1891. The manuscript he wrote with Latin letters in the Malay language Banjar was accompanied by a translation in Dutch. Later, this manuscript was reprocessed by the Commission for Customary Law (Koninklijke Instituut Voor de Taal, Land en Volkenkunde van Nederlands Indie) in the Netherlands published in Adatrecht Bundels, volume XIII of 1917. It was not only the Dutch Customary Law Commission that studied the Sultan Adam Law , Assistant Amuntai Helderman Resident on April 16, 1910, also wrote the 13th Sultan Banjar's legal product from the Suriansyah Dynasty.

Since the publication in Adatrechts Bundels 1917 the Sultan Adam Law has become quite popular among scholars of Customary Law, specifically the Banjar Customary Law both

\footnotetext{
${ }^{72}$ Satjipto Rahardjo, Membedah Hukum Progresif, h. 23.
}

among Dutch experts and indigenous experts who are interested in exploring a legal rule made by a king from the Banjar kingdom, Sultan Adam who ruled in $1825-1857$ and set the rule in $1835 .{ }^{73}$

\section{Conclusion}

The Sultan Adam Law is part of progressive law because this law is able to position itself as part of the problem solver of the problems being faced by society at that time and bring it towards a better and futuristic, and even the basic ideas of the Act Sultan Adam could inspire new laws that are more beneficial and just in the present.

At the time UUSA became the guidance of the Qadis in deciding cases and was recognized by the Dutch in the matter of the completion of the law, especially on a number of issues concerning the sect considered heretical which developed in the 18th century AD UUSA was present as a progressive law capable of responding to problems that were happened in society at that time and always tried to continually find new meanings and not be bound by absolute meanings and aimed to make the law more listened to social needs.

\section{References}

Abdurrahman. "Sejarah Perkembangan Hukum Islam di Kalimantan Selatan”, Majalah Kalimantan Scientiec, Universitas Lambung Mangkurat No. 18 Tahun VIII,1989.

Abdurrahman. "Undang-Undang Sultan Adam 1835 Dalam Perspektif Sejarah Hukum”, Jurnal AL-BANJARI, Vol. 10, No. 2, 2011.

Abdurrahman. "Undang-undang Sulthan Adam dan Kedudukannya dalam Hukum Adat Banjar”, Majalah Orientasi, Vol. 2, No. 2, Tahun 1977.

Asterina, Dina. "Penerapan Hukum Progresif Pasal 39 Undang-Undang Nomor 1 Tahun 1974 Tentang Perselisihan Suami Isteri di Pengadilan Agama Martapura”, Tesis Pascasarjana IAIN Antasari Banjarmasi, 2014.

\footnotetext{
${ }^{73}$ Abdurrahman, Undang-Undang Sultan Adam 1835..., h.
} 
Bondan, Amir Hasan Kiai. Suluh Sejarah Kalimantan, Banjarmasin: Fajar, 1953.

Daud, Alfani. Islam dan Masyarakat Banjar; Deskripsi dan Analisa Kebudayaan Banjar, Jakarta: RajaGrafindo Persada, 1997.

Effendi, Rustam. "Struktur dan Makna Undangundang Sultan Adam pada Masa Kerajaan Banjar Kalimantan Selatan”, LITERA: Jurnal Penelitian Bahasa, Sastera Dan Pengajarannya, Vol. 12, No. 2, Oktober 2013.

Eisenberger, J. Nota Betreffende Godsdienstige Rechtspraak en de Posietie der Godsdienstige Functionarissen in The Afdeeling Banjarmasinen Hoeloe Soengai der Residentis en Oosterafdeeling Banjarmasin en Hoeloe Soengai der Residentie Zuider en Oosterafdeeling Borneo, Kern Colectie, 1936.

Halidi, Yusuf, Ulama Besar Kalimantan Selatan Syekh Muhammad Arsyad Al-Banjari, Surabaya: Al Ihsan, 1984.

Joekes, A.M. Oendang-oendang Soelthan Adam, Adatrehts Bundel, Dell XIII, 1917.

Mawardi, Abu Hasan Ali bin Muhammad bin Habib al-Bushro al-Bagdadi al-. Al-Ahkam al Sulthaniyyah wa al-Wilayat al-Diniyyah, Mesir: Maktabah Syirkah, 1973, Cet. ke-3.

Nonet, Philipe dan Philipe Selznick. Law in Society in Transition Toward Responsive Law, diterjemahkan oleh Refael Edy Basco Hukum Responsif Pilihan di Masa Transisi, Jakarta: HUMA, 2003.

Noorlander, Johanes Cornelis. Banjarmasin en de Compagnie in de Tweede Helf der 18de Eeuw, M. Dubbeldeman, Leiden, 1935.

Pemerintah Propinsi Kalimantan Selatan, Sejarah Banjar, Banjarmasin: Pemerintah Propinsi Kalimantan Selatan, 2003.

Rahardjo, Satjipto. Membedah Hukum Progresif, Jakarta: Penerbit Kompas, 2007.

Ras, J.J. Hikayat Banjar a Study in Malay Histoeiography, Martinus Nijhoff: The Hague, 1968.
Ridha, M. Faqih de. "Potret Lain Perjalanan Hukum di Kerajaan Banjar", Jurnal ALBANJARI, Vol. 12, No.1, Januari 2013, ISSN 1412-9507

Roys, Kyai Haji Januri bin Haji. Sejarah Kerajaan Banjar, Singapura: Al Ahmadiyah, 1975.

Rum, H. Gusti Shuria. "Ranji/Silsilah Raja/ Sultan Kerajaan Banjar Versi Pedatuan", Makalah pada Acara Sarasehan Sejarah Kerajaan Banjarmasin, Banjarmasin, 2003.

Saleh, Gusti Hairul. Manaqib Sultan Adam AlWatsiq Billah, Martapura:Yayasan Sulthan Adam Al-Watsiq Billah, 2001.

Saleh, M. Idwar. Banjarmasin, Selayang Pandang Mengenai Bangkitnya Kerajaan Banjarmasin, Posisi, Fungsi, dan Artinya dalam Sejarah Indonesia dalam Abad ke 17, Bandung: Balai Pendidikan Guru, 1957.

Seman, Samsiar. "Meninjau Naskah Lama Undang-undang Sulthan Adam", Majalah Orientasi, No. 2, Tahun II, 1977.

Shiddiq, Syekh Abdurrahman. Risalah Sejaratul Arsyadiyah, Jakarta: Maktabah Ahmadiyah, 1937.

Usman, A. Gazali. Kerajaan Banjar Sejarah Perkembangan Politik Ekonomi Perdagangan dan Agama Islam, Banjarmasin: Lambung Mangkurat University Press, 1994.

Usman, A. Gazali. Urang Banjar Dalam Sejarah, Lambung Mangkurat University Press, Banjarmasin, 1989.

Vollenhoven, Van. Het Adatrecht Van Nederlandsch Indie, t.t: t.p., 1905.

Wertheim, W.F. Masyarakat Indonesia dalam Transisi, alih bahasa Zulfa Elizabet, Yogyakarta: Tiara Wacana, 1999.

Yamani, Reza Rahmat. Pemikiran Prof. Satjipto Rahardjo Tentang Hukum Progresif dan Relevansinya Dengan Hukum Islam Di Indonesia, Tesis Fakultas Syariah dan Hukum UIN Alauddin Makasar, 2016. 